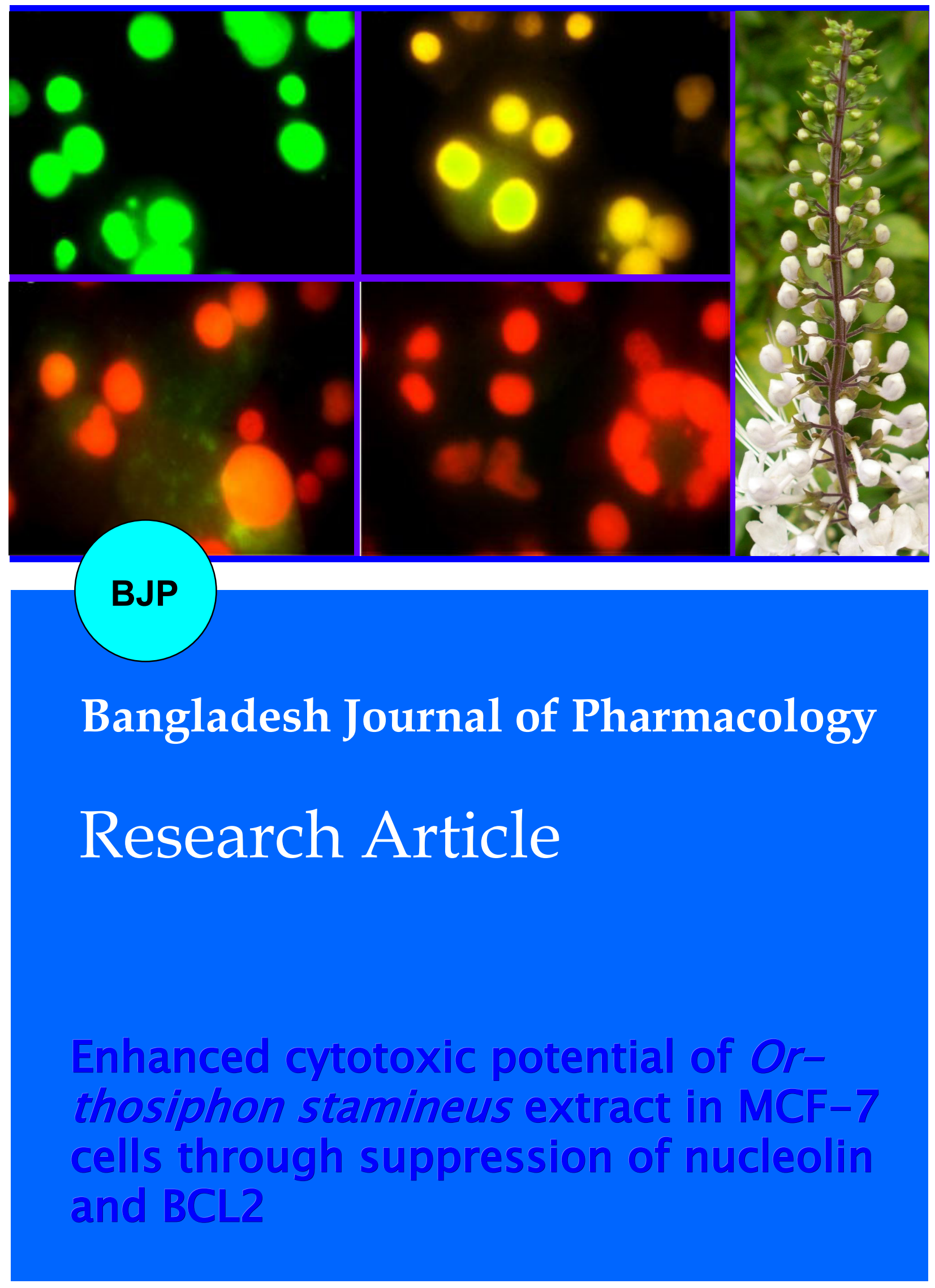


Abstracted/indexed in Academic Search Complete, Asia Journals Online, Bangladesh Journals Online, Biological Abstracts, BIOSIS Previews, CAB Abstracts, Current Abstracts, Directory of Open Access Journals, EMBASE/Excerpta Medica, Global Health, Google Scholar, HINARI (WHO), International Pharmaceutical Abstracts, Open J-gate, Science Citation Index Expanded, SCOPUS and Social Sciences Citation Index;

ISSN: $1991-0088$

\title{
Enhanced cytotoxic potential of Orthosiphon stamineus extract in MCF-7 cells through suppression of nucleolin and $\mathrm{BCL}_{2}$
}

\author{
Renuka Saravanan', Brindha Pemaiah ${ }^{2}$, Sriram Sridharan², Mahesh Narayanan ${ }^{1}$ and \\ Sivakumar Ramalingam 1 \\ ${ }^{1}$ Department of Chemistry and Biosciences, SRC, SASTRA University, Kumbakonam 612 001, Tamil Nadu, India; \\ ${ }^{2}$ Centre for Advanced Research in Indian System of Medicine, SASTRA University, Thanjavur, Tamil Nadu, India.
}

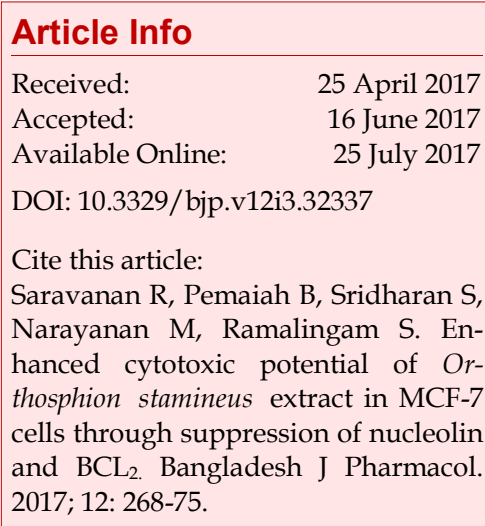

\begin{abstract}
The aim of the present study was to analyze the anti-cancer effect of Orthosiphon stamineus leaf extract on MCF-7 cells. Ethyl acetate extract of the plant was eluted and pooled into 6 fractions based on their $R_{\mathrm{f}}$ values and the fractions were tested for cytotoxicity. Fraction 3 was found effective $\left(\mathrm{IC}_{50}=\right.$ $28.5 \mu \mathrm{L} / \mathrm{mL}$ ) and was subjected to LC-MS analysis which indicated the presence of biochanin, eleutherol and cinnamic acid. Further, cytotoxic effect of the fraction was confirmed in terms of nucleolin, $\mathrm{bcl}_{2}$, bax and cytochrome c expression in MCF-7 cells through RT-PCR where a marked decrease in nucleolin, $\mathrm{bcl}_{2}$ and increase in bax and cytochrome $\mathrm{c}$ were observed. The presence of eleutherol, a well-known anti-oxidant and anti-cancer agent, has been reported for the first time in O. stamineus. The anti-cancer activity of $O$. stamineus may be due to the presence of elutherol and cinnamic acid.
\end{abstract}

\section{Introduction}

Breast cancer is one of the most frequent malignant tumors (Ferlay et al., 2012). Though there are rapid advancements in the field of medicine still an effective treatment for breast cancer is yet to be found.

Extracts from the plant in the form of pure compounds or standardized extract which is the natural product offer plenty of opportunities to discover new drug due to the availability of diverse chemical (Cosa et al., 2006). Many of the phytochemicals are safe and found to be an alternative which is effective and has less adverse effect. However, to verify the efficacy of bioactive compounds clinical trials are necessary, where some of the medicinal plants like Catharanthus roseus, Pleurotus eous (Xu et al., 2015), Taxus baccata and Bleekeria vitensis (Saravanan et al., 2014) were found to have a positive effect on breast cancer.

Orthosiphon stamineus Benth (Family Lamiaceae) is distributed plant all over Africa and Southeast Asia
(Awale et al., 2002). It is a well-known perennial herb and is used in the treatment of various diseases like influenza, jaundice, epilepsy, fever, edema, diabetes and hypertension (Ho et al., 2010).

In the previous studies, the researchers had detected the presence of terpenoids, sterols, carbohydrates, flavonoids, alkaloids, quinones, phenol and coumarins in ethyl acetate extract and flavanoids and alkaloids in methanolic extract of $O$. stamineus leaves (Saravanan et al., 2017).

Biochanin A, a vital isoflavone is a methoxylated isoflavone from red clover. This includes delayed $S$ phase in G2/M phase progression (Ying et al., 2002). It is found to be a powerful agonist of the human aryl-hydrocarbon receptor (Medjakovic and Junbauer, 2008). Cinnamic acid, a natural substances used by humans as an alternative flavoring agent and scents. It is classified under auxin, a plant hormone that helps in regulating cell growth and differentiation (Del et al., 2011). In MCF -7 cells treated with ethyl acetate fraction of $O$. 
stamineus, the expression of $\mathrm{bcl}_{2}$, nucleolin, bax, cytochrome c have been studied.

\section{Materials and Methods}

\section{Plant collection and authentication}

O. stamineus leaves were collected from Irula Tribal Women's Welfare Society, Thandrai, Tamil Nadu, India. Identification and authentication were confirmed with the help of Flora of Gamble (Manjamalai et al., 2011). Vouchers specimen was deposited at the herbarium of Centre for Advanced Research in Indian System of Medicine, SASTRA University, Thanjavur, Tamil Nadu. All the chemicals were purchased from Merck (Germany) were of HPLC reagent grade.

\section{Preparation of plant extract}

Fresh leaves of O. stamineus were washed in running water, shade dried and pulverized to coarse powder. About $100 \mathrm{~g}$ of dried sample was macerated with 150 $\mathrm{mL}$ of ethyl acetate separately and kept overnight at room temperature in a shaker. The extract was collected and dried in a vacuum rotavapor at $40^{\circ} \mathrm{C}$ followed by lyophilization using freeze dryer (Christ Martin, USA) and stored at $4^{\circ} \mathrm{C}$ till use. The crude ethyl acetate extract was fractioned by column chromatography and further analyzed with identification of molecules using LCMS/MS.

\section{Column chromatography}

Two grams of O. stamineus lyophilized sample was dissolved in $5 \mathrm{~mL}$ of ethyl acetate and allowed to dry with mixing of silica gel G (60-100 mesh). Slurry were prepared, then packed to the column $(15 \mathrm{~cm})$ with the help of $n$-hexane $(100 \%)$ followed by the mixtures of chloroform, ethyl acetate and ethanol (90:10, 80:20, 70:30 and 50:50) of increasing polarity, to obtain fractions for yellow amorphous powder. About 40 fractions were eluted with different solvents with increasing polarity. All the collected fractions were subjected to TLC analysis, based on TLC profile fractions with similar $R_{f}$ values were pooled into 6 fractions.

\section{Thin layer chromatograph (TLC) procedure}

The TLC developing was set in a twin trough chamber and was examined in various solvent systems, such as ethyl acetate and chloroform in the ratio of 1:1. The fractions were run on silica gel 60 F254, a pre-coated aluminum plate of $0.2 \mathrm{~mm}$ thickness. The plated were developed using suitable solvents and visualized with vanillin-sulfuric acid reagent. Retardation factor $\left(R_{f}\right)$ was calculated using the formula.

$\mathrm{R}_{\mathrm{f}}=\frac{\text { Distance travelled by solute }(\mathrm{cm})}{\text { Distance travelled by solvent }(\mathrm{cm})}$

Among the fractions, F1 to F6 obtained from ethyl acetate were subjected to cytotoxic effect against MCF-7 cells.

\section{Cell line}

The human breast adenocarcinoma cell lines (MCF-7) was obtained from National Centre for Cell Science (NCCS), Pune, India and grown in Eagles Minimum Essential Medium containing 10\% fetal bovine serum (FBS). The cells were maintained at $37^{\circ} \mathrm{C}, 5 \% \mathrm{CO}_{2}, 95 \%$ air and $100 \%$ relative humidity.

\section{Cell treatment procedure}

The monolayer cells were detached with trypsin-EDTA to make single cell suspensions and viable cells were counted. $100 \mu \mathrm{L}$ of $1 \times 10^{3}$ cells/well suspension were seeded into 96-well plates and incubated to allow for cell attachment with the conditions mentioned above for 24 hours. Then the cells were treated with different concentrations of the test samples, dissolved in neat dimethyl sulfoxide (DMSO). Following sample addition, the plates were incubated further for 48 hours with the conditions previously mentioned. The medium alone served as control and triplicate was maintained for all concentrations (Mosmann, 1983).

\section{MTT assay}

Cytotoxic assay on MCF-7 with different concentration of ethyl acetate fraction was performed by the method described elsewhere (Monks et al., 1991). 3-[4,5dimethylthiazol-2-yl]2,5-diphenyltetrazolium bromide (MTT) is a yellow water soluble tetrazolium salt. A mitochondrial enzyme in living cells, succinate-dehydrogenase, cleaves the tetrazolium ring, converting the MTT to an insoluble purple formazan. Therefore, the amount of formazan produced is directly proportional to the number of viable cells. After 48 hours of incubation, $15 \mu \mathrm{L}$ of MTT $(5 \mathrm{mg} / \mathrm{mL})$ in phosphate buffered saline (PBS) was added to each well and incubated at $37^{\circ} \mathrm{C}$ for 4 hours. The medium with MTT was then flicked off and the formed formazan crystals were solubilized in $100 \mu \mathrm{L}$ of DMSO and then measured the absorbance at $570 \mathrm{~nm}$ using micro plate reader. The \%cell inhibition was determined using the following formula.

$\%$ Cell inhibition $=\left(100-\mathrm{Abs}_{\text {sample }} / \mathrm{Abs}_{\mathrm{control}}\right) \times 100$

Nonlinear regression graph was plotted between \%cell inhibition and $\log$ concentration and $\mathrm{IC}_{50}$ was determined using GraphPad Prism software.

\section{LC-MS/MS}

$500 \mu \mathrm{L}$ of $\mathrm{F} 3$ was subjected to LC/ESI/MS/MS using UHPLC+ focused (Ultra high performance liquid chromatography) RP liquid chromatography coupled to mass spectrometer (micrOTOF-Q II, Bruker, Germany). Liquid chromatography separations were carried out on a C18 reverse phase column (120 ̊, 2.1 x $150 \mathrm{~mm}$ 
Acclaim 120, UHPLC+ Ultimate 3000 series, Dionex). UV detector was set arbitrarily at $260 \mathrm{~nm}$. A discontinuous gradient elution at a flow rate of $0.2 \mathrm{~mL} / \mathrm{min}$ was performed using mobile phase A (acetonitrile) and B (water-MilliQ acidified with $0.1 \%$ formic acid). Mass spectrometer with ESI ionization at negative mode equipped with HyStar 3.2 software was optimized to detect the exact mass and mass fragmentation pattern of each eluted compound. TIC spectra were acquired and elaborated using the HyStar software data analysis module. MS/MS experiments were carried out by means of auto scanning mode, where the mass spectrometer software made a choice in real time about the selection of ion to fragment based on the intensity of each peaks with a threshold set above 1500 absolute counts. Optimized parameters consisted in collision energy $10 \mathrm{eV}$, focusing potential of $350 \mathrm{Vpp}$ (Voltage per peak), transfer time of $80 \mu \mathrm{S}$, pre pulse storage of 5 $\mu S$ the instrument was operated in the negative ion mode with a capillary voltage of $3.5 \mathrm{KV}$, capillary temperature was $280^{\circ} \mathrm{C}$, sheath gas $\left(\mathrm{N}_{2}\right)$ flow rate was 6 $\mathrm{L} / \mathrm{min}$ and the data were acquired in the AutoMSn scanning modes. Scan range was m/z 50- 1500; number of microscan was set at 3 (Arun et al., 2014).

\section{RT-PCR}

Expression of nucleolin, $\mathrm{bcl}_{2}$, cytochrome $\mathrm{c}$ and $\beta$-actin in fraction 3 treated MCF-7 cells were determined by semiquantitative RT-PCR. Total RNA or poly (A) + selected RNA were used as template for RT-PCR and primed with random primers, oligo $(\mathrm{dT})$, or a genespecific primer (GSP) using a reverse transcriptase .

The MCF-7 cells $\left(1 \times 10^{5}\right.$ cells/group) were treated with no (control) or with different concentration (10, 20, 40 ug) of ethyl extract sample of O. stamineus. After 24 hours of treatment, the medium was completely removed from the flask and the total RNA was isolated using Trizol reagent (Sigma). Using the total RNA as template, cDNA was synthesized as per the manufacturer's instruction. The RT-PCR for apoptotic genes was performed in a total volume of $20 \mu \mathrm{L}$ reaction mixture containing random primer pairs (forward and reverse $0.5+0.5 \mu \mathrm{L}$ concentration) $1.0 \mu \mathrm{L}, 10 \mathrm{x}$ reaction buffer containing master mix (25 mM $\mathrm{MgCl}_{2}, 10 \mathrm{mM}$ dNTPs, Taq polymerase $2.5 \mathrm{U}) 10 \mu \mathrm{L}$, cDNA as template $2 \mu \mathrm{L}$ and remaining volume is nuclease free $\mathrm{dH}_{2} \mathrm{O} 7 \mu \mathrm{L}$. Amplification cycles consisted of denaturation at $94^{\circ} \mathrm{C}$ for $1 \mathrm{~min}$, primer annealing at $55^{\circ} \mathrm{C}$ for $40 \mathrm{sec}$ and extension at $72^{\circ} \mathrm{C}$ for $1 \mathrm{~min}$, for a total of 32 cycles followed by final extension at $72^{\circ} \mathrm{C}$ for $10 \mathrm{~min}$ (Paulpandi et al., 2012).

\section{Fluorescence microscopic analysis of apoptotic cell death}

Approximately $1 \mu \mathrm{L}$ of a dye mixture (acridine orange (AO) and ethidium bromide (EtBr) each $100 \mathrm{mg} / \mathrm{mL}$ in distilled water) was mixed with $9 \mathrm{~mL}$ of cell suspension $\left(1 \times 10^{5}\right.$ cells $\left./ \mathrm{mL}\right)$ on clean microscope cover slips. The selected cancer and normal cells were collected, washed with phosphate buffered saline (PBS) ( $\mathrm{pH}$ 7.2) and stained with $1 \mathrm{~mL}$ of $\mathrm{AO} / \mathrm{EtBr}$. After incubation for 2 min, the cells were washed twice with PBS (5 min each) and visualized under a fluorescence microscope (Nikon Eclipse, Inc, Japan) at 400x magnification with an excitation filter at $480 \mathrm{~nm}$. Likewise the cells were placed on glass coverslip in a 24 -well plate and treated with complex for 24 hours. The fixed cells were permeabilised with $0.2 \%$ triton $\mathrm{X}-100(50 \mu \mathrm{L})$ for $10 \mathrm{~min}$ at room temperature and incubated for $3 \mathrm{~min}$ with $10 \mu \mathrm{L}$ of DAPI by placing a coverslip over the cells to enable uniform spreading of the stain. The cells were observed under (Nikon Eclipse, Inc, Japan) fluorescent microscope.

\section{Results}

Various fractions were obtained from column chromatography with different solvents, in the order of increasing polarity. Totally 40 fractions were eluted, among the fractions F1 to F6 obtained from ethyl acetate were subjected to cytotoxic effect against MCF-7 cells. The $\mathrm{IC}_{50}$ values for the fractions were at 33.0, 85.2, 28.5, 84.7 67.2 and $56.4 \mu \mathrm{L} / \mathrm{mL}$ respectively (Figure 1 ). Of the six fractions $\mathrm{F} 3\left(\mathrm{IC}_{50} 28.5 \mu \mathrm{L} / \mathrm{mL}\right.$ ) represents good cytotoxic effect against MCF-7 cells. Thus, F3 was subjected to LC-MS analysis, presence of isoflavaones- biochanin, eleutherol-napthofuran, and cinnamic acid which were detected in LC/MS/MS analysis (Figure 2).

Phytochemical investigation on ethyl acetate fraction 3 of the O. stamineus led to the identification of a complex mixture of flavonoids predominantly containing biochanin A-O-rhamnoside, eleutherol and cinnamic acido-hexoside. Using negative ionization mode these base peaks were identified as deprotonated molecule [M-H]. The retention time and the mass to charge ratios $(\mathrm{m} / \mathrm{z})$ of the base peaks and its respective fragmented peaks

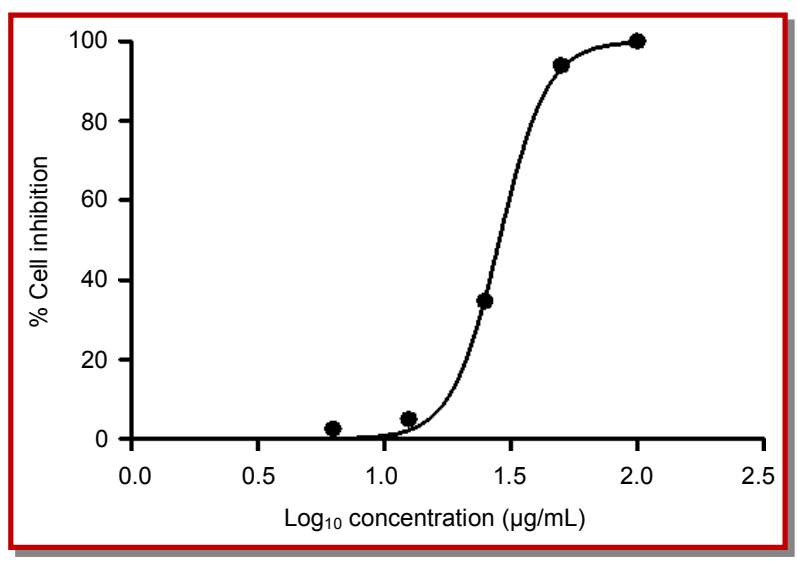

Figure 1: Cytotoxic effect of O. stamineus ethyl acetate fraction 3 on MCF-7 cells 


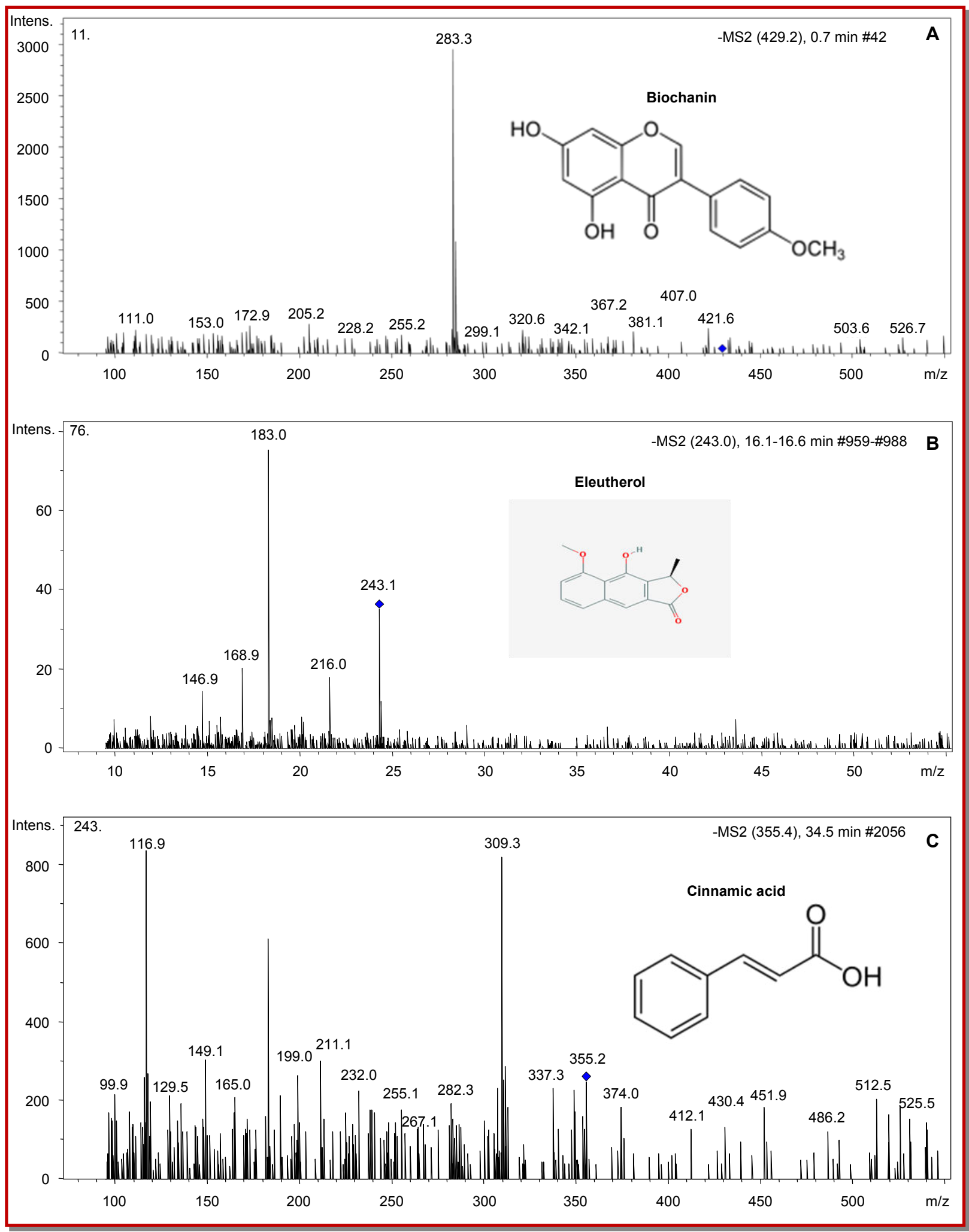

Figure 2: LC-MS/MS spectrum of ethyl acetate fractions of $O$. stamineus leaves. A) Biochanin, B) Elutherol and C) Cinnamic acid 
Table I

ESI-MS and ESI-MSMS product ions of fractions from ethyl acetate extract of $O$. stamineus leaves

\begin{tabular}{|lrrr|}
\hline Identified compound & Rt [min] & Mass & $\begin{array}{c}\text { Parent ion } \\
\text { [M-H]- }\end{array}$ \\
\hline Biochanin A-O- rhamnoside & & 430 & 429 \\
Eleutherol & $16.1-16.6$ & $283,367,77,74$ \\
Cinnamic acid-o-hexoside & 34.5 & 356 & 243 \\
\hline
\end{tabular}

are listed in Table I. Most of the phytomolecules identified were eluted at 0.7-34.5 $\mathrm{min}$ and then later at $35-45 \mathrm{~min}$. It was also observed that all the identified flavone glucosides were eluted with 21- $32 \%$ acetonitrile in acidified water (14-24 min), similarly majority of identified flavones/flavonols were eluted with increase in acetonitrile content nearing to $100 \%$ (35 $-45 \mathrm{~min})$.

It has been observed that a dose-dependent decrease in nucleolin and $\mathrm{bcl}_{2}$ expression with concomitant increase in bax and cytochrome c expression in MCF-7 cells (Figure 3). Data was analyzed using image J software and the intensity values were schematically represented by densitometry analysis.

\section{Fluorescence microscopy analysis of nuclear fragmen-} tation

Fluorescence microscopy images of MCF-7 cancer cells in the absence and presence of compounds are shown in Figure 4. From the images, untreated MCF-7 cancer cells (control) did not show any significant adverse

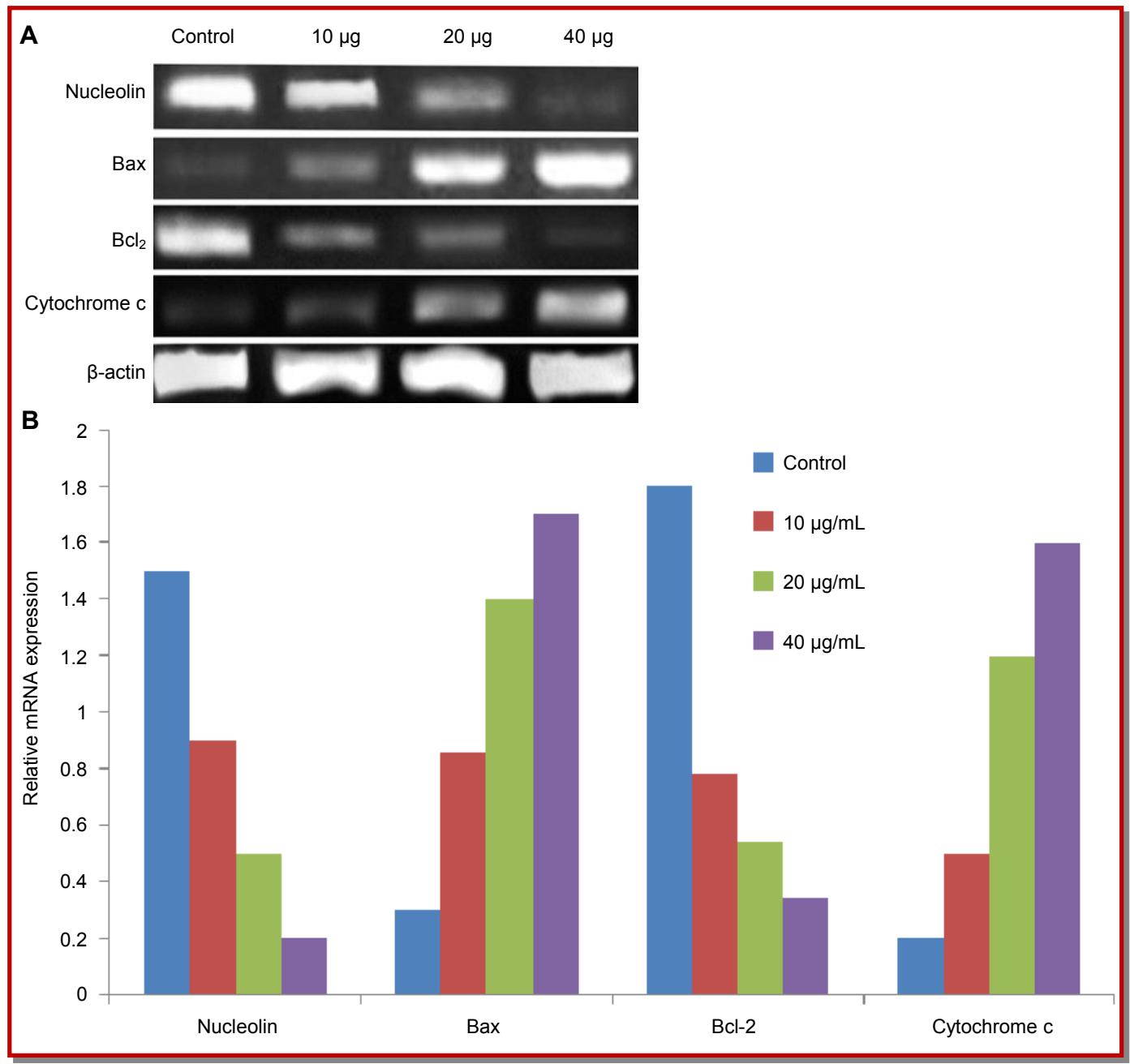

Figure 3: Expression level of nucleolin, $\mathrm{bcl}_{2}$, cytochrome $\mathrm{c}$ and bax in MCF-7 cell extract treated with different concentration of ethyl acetate extract of $O$. stamineus (A); Graphical representation of expression level of nucleolin, bcl ${ }_{2}$, cytochrome c and bax was determined by RT-PCR in MCF-7 cell extract (B) 
effect as compared to cells treated with fractions. It has also been observed a concentration dependent change in apoptotic effect which is significant.
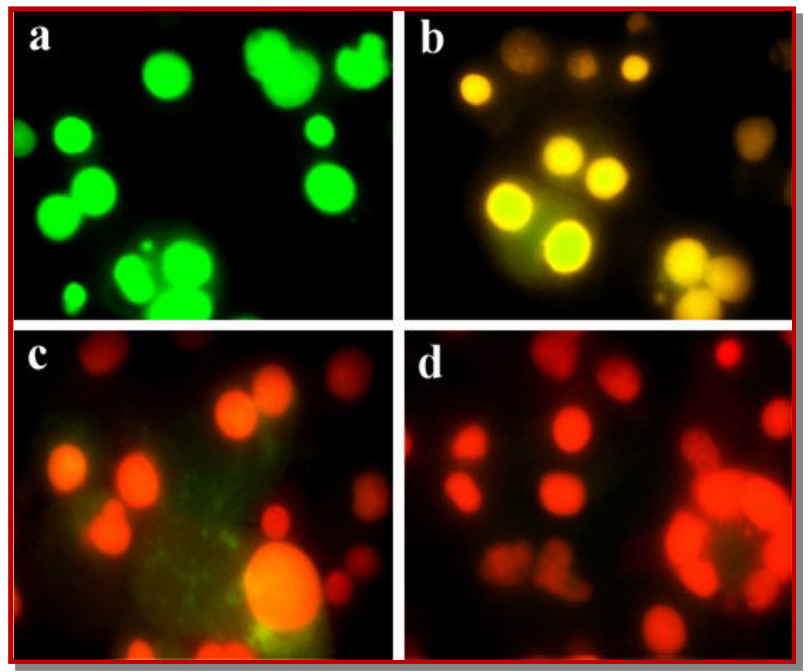

Figure 4: Fluorescent microscopic analysis of MCF-7 cells treated with ethyl acetate extract of $O$. stamineus leaves; a) Control, b) $10 \mu \mathrm{g} / \mathrm{mL}$; c) $20 \mu \mathrm{g} / \mathrm{mL}$; d) $40 \mu \mathrm{g} / \mathrm{mL}$

\section{Discussion}

The cytotoxic effect of fraction 3 on MCF cells was promising. It could be due to the presence of biochanin, eleutherol and cinnamic acid in the extract. These compounds were reported as antitumor and antioxidant agents. Decreased level of $\mathrm{bcl}_{2}$ and nucleolin with concomitant decrease in bax and cytochrome $c$ could induce apoptosis in MCF cells. However, the exact mechanism of down-regulation of $\mathrm{bcl}_{2}$ and nucleolin and up-regulation of cytochrome $\mathrm{c}$ and Bax by the identified compounds remains to be explored.

The biochanin A, the flavanoid compound 1 which is isolated from ethyl acetate fractions of $O$. stamineus was identified by LC-MS with the published data in literature (Medjakovic and Jungbauer, 2007).

The occurrence of biochanin A in large quantities in the leaves of $O$. stamineus isoflavanoids have been screened for their pharmacological effects such as anti-inflammatory, antitumor, hypotensive, locomotor and bioassay studies were reported. Studies showed that cell cycle analyses of biochanin A treatment showed an obvious delayed mitosis and this phenotype was associated with the elevation of p21. Elevation of p21 after PLK-1 inhibition might be a general phenomenon in normal and cancer cells (Kreis et al., 2009). In normal cells, stabilization of p21 induces PLK-1 depletion, which causes the elevation of p53. In cancer cells (p53defective), PLK-1 depletion reduced Mdm2 expression, a negative regulator of p21 protein stability (Lei and Erikson, 2008). Thus, anti-cancer effects of biochanin A was associated with down-regulation of PLK-1 and upregulation of p21 mechanism.
Researchers suggest that biochanin A selectively inhibits SK-BR-3 breast cancer cells as compared to MCF-10A normal breast epithelial and NIH-3T3 normal fibroblast cells. It also indicates that biochanin A has a biphasic effect on SK-BR-3 cell viability with increased cell viability at subapoptotic concentrations $(2-20 \mu \mathrm{M})$ and a dose-dependent inhibition of cell viability at higher concentrations (Sehdev et al., 2009).

Eleutherol is a napthofuran, one of its derivatives eleutherine showed interesting inhibitory activity against human topoisomerase II, and compounds with this action can be considered as part of first-line chemotherapy for a wide variety of tumors (Kusuma et al., 2010).

Cinnamic acids are abundant in various natural resources. Cinnamic acid and its natural analogues are known for the treatment of cancer for over centuries. 2Methyl cinnamide isolated from a fermentation beer of Streptomyces griseoluteus, showed significant antiinvasive or antimetastatic effects (Del et al., 2011). Natural products bearing the cinnamoyl moiety have attached much attention due to their broad spectrum of biological activities and low toxicity. Additionally, trans -cinnamic acid derivatives, both isolated from plant sources and synthesized, are well known for their antioxidant (Chung and Shin, 2007), antitumor (Bezerra et al., 2006), antimicrobial (Naz et al., 2006) and antimycobacterial properties (Carvalho et al., 2008). Cinnamic acid derivatives, especially those combining the cinnamoyl moiety with hydroxyl groups, present strong free radical scavenging properties.

$\mathrm{Bcl}_{2}$ protein is an anti-apoptotic protein, its overexpression has been implicated in different type of cancer and associated with resistance to chemotherapy (Myer et al., 1997). Overexpression of $\mathrm{bcl}_{2}$ protein is the result of enhanced stability of $\mathrm{bcl}_{2}$ mRNA, which is controlled by AU rich element present in the 3' UTR region. Nucleolin is highly conserved among eukaryotes and is ubiquitously expressed. It has been reported that nucleolin protein binds with $\mathrm{AU}$ rich elements of $\mathrm{bcl}_{2-}$ mRNA and thereby increases the stability of the mRNA (Ishimaru et al., 2010). We observed a dose-dependent decreased level of the expression of nucleolin and $\mathrm{bcl}_{2}$, on contrary, increased the level of bax and cytochrome c in MCF-7 cell. Bax, a bcl ${ }_{2}$ family protein, interacts with $\mathrm{bcl}_{2}$ protein and induces apoptosis. Bax is reported to increase the opening of the mitochondrial voltagedependent anion channel, which leads to the loss in membrane potential and the release of cytochrome c. The increase in bax and cytochrome $\mathrm{c}$ is in accordance with the previous findings (Gómez et al., 2013).

AS1411, an aptamer which is a short G-rich oligonucleotide, forms G-quadruplex structure which is resistant to serum enzymes. This compound was reported to decrease the level of nucleolin and $\mathrm{bcl}_{2}$ in MCF-7 cells (Sridharan et al., 2008). Baicalein, a flavanoid, induces 
apoptosis in cancer cells.

Most of the studies reveal that the $\mathrm{bcl}_{2}$ protein prevents apoptotic mechanism, whereas bax protein induce the cell death in cancer cells. Down-regulation of $\mathrm{bcl}_{2}$ leads to the release of cytochrome $c$ from mitochondria to the cytosol, resulting in cell death. Eriocalyxin B inhibits the proliferation and induces apoptosis through downregulation of $\mathrm{bcl}_{2}$ (Rasul et al., 2013). Studies examined that the cellular levels of cytochrome $c$, caspase 3, PARP, p53, bax, $\mathrm{bcl}_{2}$ and $\beta$-actin expression after baicalein treatment. This compound was reported to increase the expression of bax and cytochrome $c$ (Krishnamoorthy et al., 2016).

\section{Conclusion}

The ethyl acetate fraction of $O$. staminues leaves revealed that the presence of biochanin, eleutherol and cinnamic acid. A marked decrease of nucleolin and bcl2 expression level was observed in MCF cells treated with the fraction. It is clear that ethyl acetate fraction showed up-regulation of pro-apoptotic and genes and down-regulation of anti-apoptotic genes, which in turn induces apoptosis. This is the first report eluetherol isolated from the leaf of $O$. stamineus.

\section{Conflict of Interest}

All authors have completed the ICMJE uniform disclosure form and declare no support from any organization for the submitted work.

\section{References}

Arun PK, Rajesh SS, Sundaram SM, Sivaraman T, Pemiah B. Structural characterizations of lead anti-cancer compounds from the methanolic extract of Jatropha tanjorensis. Bangladesh J Pharmacol. 2014; 9: 452-65.

Awale S, Tezuka Y, Banskota AH, Shimoji S, Taira K, Kadota S. Norstaminane and isopimarane-type diterpenes of $O$. stamineus from Okinawa. Tetrahedron 2002; 58: 5503-12.

Bezerra DP, Castro FO, Alves APNN, Pessoa C, Moraes MO, Silveira ER, Lima MAS, Elmiro FJM, Costa-Lotufo LV. In vivo growth-inhibition of Sarcoma 180 by piplartine and piperine, two alkaloid amides from Piper. Braz J Med Biol Res. 2006; 39: 801-07.

Carvalho SA, Da Silva EF, De Souza MVN, Lourenço MCS, Vicente FR. Synthesis and antimycobacterial evaluation of new trans-cinnamic acid hydrazide derivatives. Bioorg Med. Chem Lett. 2008; 18: 538-41.

Chung HS, Shin JC. Characterization of anti-oxidant alkaloids and phenolic acids from anthocyanin-pigmented rice (Oryza sativa cv. Heugjinjubyeo). Food Chem. 2007; 104: 1670-77.

Cosa P, Vlietinck A J, Berghe D V, Maes L. Anti-infective potential of natural products: How to develop a stronger in vitro 'proof-of-concept'. J Ethnopharmacol. 2006; 106: 290302.

Del P, Baltas M, Bedos-Belval F. Cinnamic acid derivatives as anti-cancer agents: A review. Curr Med Chem. 2011; 18; 1672 -1703 .

Ferlay E, Steliarova-Foucher J, Lortet-Tieulent et al. Cancer incidence and mortality patterns in Europe: Estimates for 40 countries in 2012. Eur J Cancer. 2013; 49.

Gómez-Crisóstomo NP, López-Marure R, Zapata E, Zazueta C, Martínez-Abundis E. Bax induces cytochrome c release by multiple mechanisms in mitochondria from MCF-7 cells. J Bioenerg Biomembr. 2013; 5: 441-48.

Ho $\mathrm{CH}$, Noryati I, Sulaiman SF, Rosma A. In vitro antibacterial and anti-oxidant activities of Orthosiphon stamineus Benth. extracts against food-borne bacteria. Food Chem. 2010; 122: 1168-72.

Ishimaru D, Zuraw L, Ramalingam S, Sengupta TK, Bandyopadhyay S, Reuben A, Fernandes DJ, Spicer EK. Mechanism of regulation of bcl-2 mRNA by nucleolin and A+U-rich element-binding factor 1 (AUF1). J Biol Chem. 2010; 35: 27182-91.

Kreis NN, Sommer K, Sanhaji M, Kramer A, Matthess $Y$, Kaufmann M, Strebhardt K, Yuan J. Long-term downregulation of polo-like kinase 1 increases the cyclindependent kinase inhibitor p21 (WAF1/CIP1). Cell Cycle. 2009; 8: 460-72.

Krishnamoorthy K, Manickam P, Palghat RP, Sundaravadivelu S. Induction of intrinsic apoptotic pathway and cell cycle arrest via baicalein loaded iron oxide nanoparticles as a competent nano-mediated system for triple negative breast cancer therapy. RSC Adv. 2016; 6: 64531-43.

Kusuma IW, Arung ET, Rosamah E, Purwatiningsih S, Kuspradini H, Syafrizal, Astuti J, Kim YU, Shimizu K. Antidermatophyte and antimelanogenesis compound from Eleutherine americana grown in Indonesia. J Nat Med. 2010; 64: 223-26.

Lei M, Erikson RL. Plk1 depletion in nontransformed diploid cells activates the DNA damage checkpoint. Oncogene 2008; 27: 3935-43.

Leitzmann M, Powers H, Anderson AS et al. European code against cancer. 4th ed. Physical activity and cancer. Cancer Epidemiol. 2015; 39: S46-S55.

Paulpandi M, Kannana S, Thangam R, Kaveri K, Gunasekaran $\mathrm{P}$, Rejeetha C. In vitro anti-viral effect of $\beta$-santalol against influenza viral replication. Phytomedicine 2012; 19: 231-35.

Manjamalai A, Narala Y, Haridas A, Grace VM. Antifungal, anti-inflammatory and GCMS analysis of methanolic extract of Plectranthus amboinicus leaf. Int J Curr Pharm Res. 2011; 2: 129-36.

Medjakovic S, Jungbauer A. Red clover isoflavones biochanin $A$ and formononetin are potent ligands of the human aryl hydrocarbon receptor. J Steroid Biochem Mol Biol. 2008; 108: 171-77.

Monks A, Scudiero D, Skehan P, Shoemaker R, Paull K, Vistica D, Hose C, Langley J, Cronise P, Vaigro-Wolff A, GrayGoodrich M, Campbell H, Mayo J, Boyd. Feasibility of high flux anti-cancer drug screen using a diverse panel of 
cultured human tumour cell lines. J Natl Cancer Inst. 1991; 83: 757-66.

Mosmann T. Rapid colorimetric assay for cellular growth and survival: Application to proliferation and cytotoxicity assays. J Immunol Methods. 1983; 65: 55-63.

Myer VE, Fan XC, Steitz JA. Identification of HuR as a protein implicated in AUUUA-mediated mRNA decay. EMBOJ. 1997; 8: 2130-39.

Naz S, Ahmad S, Rasool AS, Sayeed AS, Siddiqi R. Antibacterial activity directed isolation of compounds from Onosma hispidum. Microbiol Res. 2006;161: 43-48.

Rasul A, Liu J, Liu Y, Millimouno F, Wang X, Tsuji I, Yamamura T, Li J, Li, X. Eriocalyxin B inhibits proliferation and induces apoptosis through down-regulation of Bcl-2 and activation of caspase-3 in human bladder cancer cells. Bangladesh J Pharmacol. 2013; 8: 116-23.

Saravanan R, Brindha P, Ramalingam S. A review on the role of phytoconstituents in breast cancer cells. Int J Pharm Tech Res. 2014; 6: 799-808.
Saravanan R, Pemiah B, Narayanan M, Ramalingam S. In vitro cytotoxic and gas chromatography-mass spectrometry studies on $O$. stamineus Benth. (Leaf) against MCF-7 cell lines. Asian J Pharm Clin Res. 2017; 3: 1-7.

Sridharan S, Weiwei C, Eleanor KS, Nigel CL, Daniel JF. The nucleolin targeting aptamer AS1411 destabilizes Bcl-2 messenger RNA in human breast cancer cells. Cancer Res. 2008; 68: 2358-65.

Sehdev V, Lai JCK, Bhushan A. Biochanin A modulates cell viability, invasion, and growth promoting signaling pathways in HER-2-positive breast cancer cells. J Oncol. 2009, 2009.

$\mathrm{Xu}$ J, Yuan Q, Luo P, Sun X, Ma J. Pleurotus eous polysaccharides suppress angiogenesis and induce apoptosis via ROS-dependent JNK activation and mitochondrial mediated mechanisms in MCF-7 human breast cancer cells. Bangladesh J Pharmacol. 2015; 10: 78-86.

Ying C, Hsu JT, Hung HC, Lin DH, Chen LF, Wang LK. Growth and cell cycle regulation by isoflavones in human breast carcinoma cells. Reprod Nutr Dev. 2002; 42: 55-64. 